\title{
TINJAUAN HUKUM PERKAWINAN BEDA AGAMA DAN AKIBAT HUKUMNYA MENURUT UNDANG-UNDANG NOMOR 1 TAHUN 1974 TENTANG PERKAWINAN
}

\author{
Hanum Farchana Devi;Mastur \\ Fakultas Hukum Universitas Wahid Hasyim Semarang \\ hanumdevi30@gmail.com; mastur_unwahas@yahoo.com
}

\begin{abstract}
Abstrak
Di Indonesia, perkawinan memang bukanlah sebuah persoalan yang rumit manakala pasangan memeluk agama yang sama, namun akan menjadi persoalan yang sangat rumit apabila kedua pasangan tersebut memeluk agama yang berbeda. Hal ini menjadi masalah karena dengan adanya perbedaan agama maka pelaksanaan perkawinan menjadi terhalang. Permasalahannya adalah bagaimana perkawinan berbeda agama menurut Undang-undang Nomor 1 Tahun 1974 dan apa akibat hukum dari perkawinan berbeda agama di Indonesia. Metode penelitian yang digunakan adalah yuridis normatif, maksudnya adalah penelitian yang dilakukan dengan cara mengkaji peraturan perundang-undangan beserta peraturan lainnya yang relevan dengan permasalahan yang diteliti. Adapun peraturan perundang-undangan yang dikaji dalam penelitian ini adalah peraturan perundangundangan yang terdapat kaitannya dengan masalah perkawinan berbeda agama seperti Undang-undang Nomor 1 Tahun 1974 tentang perkawinan dan Kompilasi Hukum Islam.Hasil penelitian menjelaskan bahwa perkawinan yang dilakukan antara kedua mempelai yang berbeda agama maka perkawinannya adalah tidak sah menurut agama yang berarti juga tidak sah menurut Undang-undang Nomor 1 Tahun 1974.Akibat hukum dari perkawinan berbeda agama di Indonesia adalah status perkawinan berbeda agama tersebut tidak sah menurut masing-masing agama sehingga tidak sah pula menurut Undang-undang Nomor 1 Tahun 1974.Dengan adanya status perkawinan yang tidak sah tersebut maka membawa akibat hukum juga terhadap status dan kedudukan anak.Anak-anak yang dilahirkan dari perkawinan berbeda agama adalah anak tidak sah atau anak luar kawin karena perkawinan kedua orangtuanya bukan merupakan perkawinan yang sah, maka akibatnya adalah anak tersebut tidak memiliki hubungan perdata dengan ayahnya, si anak hanya memiliki hubungan perdata dengan ibu dan keluarga ibunya saja.Hal tersebut sesuai dengan Pasal 43 ayat (1) Undang-Undang Nomor 1 Tahun 1974 dan Pasal 100 Kompilasi Hukum Islam.
\end{abstract}

Kata kunci: perkawinan beda agama, Undang-undang Nomor 1 Tahun 1974 Tentang Perkawinan

\section{A. Pendahuluan}


Perkawinan merupakan peristiwa yang sangat penting dalam kehidupan yang bertujuan untuk mempunyai keturunan. ${ }^{1}$ Masyarakat Indonesia adalah masyarakat yang majemuk khususnya bila dilihat dari segi agamanya.Dengan adanya kemajemukan itulah diharapkan dapat mempersatukan masyarakat satu dengan masyarakat yang lainnya. Namun ada satu persoalan masyarakat dalam hubungan antar umat beragama yaitu masalah perkawinan, perkawinan seorang muslim dengan non muslim atau lebih terkenal disebut dengan perkawinan berbeda agama.

Di Indonesia, perkawinan memang bukanlah sebuah persoalan yang rumit manakala pasangan memeluk agama yang sama, namun akan menjadi persoalan yang sangat rumit apabila pasangan tersebut memeluk agama yang berbeda. Hal ini menjadi masalah karena dengan adanya perbedaan agama maka pelaksanaan perkawinan menjadi terhalang. Lalu bagaimana cara melaksanakan perkawinan berbeda agama tersebut.

Di Indonesia telah ada Undang-undang yang mengatur tentang perkawinan yaitu Undang-undang Nomor 1 Tahun 1974.Pada Pasal 2 ayat (1) telah diatur mengenai keabsahan suatu perkawinan yaitu perkawinan adalah sah apabila dilakukan menurut hukum masing-masing agamanya dan kepercayaannya itu. ${ }^{2}$ Jika Undang-undang Nomor 1 Tahun 1974 telah mengatur bahwa sahnya suatu perkawinan adalah apabila perkawinan tersebut dilaksanakan menurut hukum agamanya masing-masing, lalu bagaimana dengan pasangan yang ingin melaksanakan perkawinan dengan agama yang berbeda di Indonesia dan bagaimana akibat hukum apabila perkawinan berbeda agama dilaksanakan di Indonesia.

Adapun permasalahannya adalah sebagai berikut.

1. Bagaimana perkawinan berbeda agama menurut Undang-undang Nomor 1 Tahun 1974 Tentang Perkawinan?

2. Bagaimana akibat hukum dari perkawinan berbeda agama di Indonesia?

\footnotetext{
${ }^{1}$ Soedharyo, Soimin, Hukun Orang dan Keluarga Perspektif Hukum Perdata Barat/BW, Hukum Islam, dan Hukum Adat, (Jakarta : Sinar Grafika, 2004), halaman 3

${ }^{2}$ Subekti dan Tjitrosudibio, Kitab Undang-Undang Hukum Perdata, (Jakarta : Pradnya Paramita, 2004), halaman 538
} 


\section{B. Metode Penelitian}

Metode penelitian yang digunakan adalah yuridis normatif, maksudnya adalah penelitian yang dilakukan dengan cara mengkaji peraturan perundangundangan beserta peraturan lainnya yang relevan dengan permasalahan yang diteliti. $^{3}$ Adapun peraturan perundang-undangan yang dikaji dalam penelitian ini adalah peraturan perundang-undangan yang terdapat kaitannya dengan masalah perkawinan berbeda agama seperti Undang-undang Nomor 1 Tahun 1974 tentang perkawinan dan Kompilasi Hukum Islam.

\section{Pembahasan}

\section{Perkawinan Berbeda Agama Menurut Undang-Undang Nomor 1 Tahun 1974 Tentang Perkawinan}

1.) Perkawinan berbeda agama menurut agama di Indonesia

a. Perkawinan berbeda agama menurut agama Islam

Menurut hukum Islam, perkawinan baru dapat dikatakan sah apabila telah memenuhi rukun, syarat dan tidak melanggar larangan perkawinan. ${ }^{4}$ Adapun rukun nikah terdiri dari :

a.) Adanya calon mempelai laki-laki dan perempuan

b.) Harus ada wali

c.) Disaksikan oleh dua orang saksi

d.) Ijab dan Kabul

Adapun syarat-syarat perkawinan menurut agama Islam adalah :

a.) Ijab kabul

b.) Calon mempelai laki-laki dan perempuan

c.) Perkawinan tidak boleh dipaksakan

d.) Wali nikah

e.) Saksi

\footnotetext{
${ }^{3}$ Muh. Abdul Kadir, Hukum dan Penelitian Hukum, (Bandung : PT. Citra Aditya Bakti, 2004), halaman 116

${ }^{4}$ Asmin, Status Perkawinan Antar Agama Ditinjau Dari Undang-Undang Perkawinan Nomor 1/1974, (Jakarta: PT Dian Rakyat, 1986), halaman 29
} 
f.) Mahar

Adapun larangan perkawinan dalam agama Islam adalah sebagai berikut :

a.) Larangan perkawinan karena hubungan darah yang terlampau dekat

b.) Larangan merujuk bekas isteri yang telah dijatuhi talak tiga, kecuali setelah si isteri tersebut kawin lagi dengan orang lain dan kemudian dia bercerai dengan suaminya tersebut

c.) Larangan perkawinan karena perbedaan agama.

Dilihat dari penjelasan tersebut bahwa salah satu larangan dalam perkawinan adalah larangan perkawinan karena perbedaan agama.Dengan adanya larangan tersebut, jelas bahwa agama Islam tidak memperbolehkan atau melarang adanya perkawinan berbeda agama.

b. Perkawinan berbeda agama menurut agama Kristen

Gereja Kristen menyatakan bahwa sahnya suatu perkawinan adalah bahwa perkawinan harus dilaksanakan sesuai dengan hukum negara dan hukum Tuhan. Sesuai dengan hukum negara yaitu pernikahan tersebut di catatkan di Kantor Catatan Sipil agar pernikahan tersebut diakui sah secara yuridis oleh hukum negara sedangkan sesuai hukum agama yaitu dengan memenuhi syarat-syarat pernikahan yaitu sebagai berikut :

a.) Masing-masing pihak tidak terikat tali perkawinan dengan pihak lain

b.) Kedua calon mempelai beragama Kristen

c.) Harus dihadiri oleh saksi

d.) Disaksikan oleh jemaat

Berdasarkan syarat-syarat tersebut, disebutkan bahwa syarat perkawinan menurut agama Kristen adalah kedua calon mempelai beragama Kristen yang artinya adalah agama Kristen tidak memperbolehkan salah satu mempelai beragama Non Kristen.Jadi dapat disimpulkan bahwa menurut agama Kristen perkawinan berbeda agama tidak di perbolehkan.

c. Perkawinan berbeda agama menurut agama Katolik

Menurut agama Katolik, pernikahan yang sah adalah pernikahan yang dilakukan, diteguhkan dan diberkati oleh Pejabat Gereja yang dihadiri oleh dua 
orang saksi dan telah memenuhi syarat-syarat pernikahan. Syarat-syarat pernikahan tersebut adalah sebagai berikut :

a.) Calon mempelai sudah mengerti makna penerimaan sakramen perkawinan beserta akibat-akibatnya

b.) Tidak berdasarkan paksaan (Kan 1103)

c.) Pria sudah berumur 16 tahun dan wanita sudah berumur 14 tahun (Kan 1083 : 1)

d.) Tidak terikat tali perkawinan dengan pihak lain (Kan $1085: 1$ )

e.) Beragama Katolik (Kan1086:1)

f.) Dan tidak melanggar larangan perkawinan.

Dari syarat-syarat pernikahan yang telah disebutkan diatas, ada syarat yang menyatakan bahwa tidak boleh melanggar larangan perkawinan. Adapun larangan perkawinan yang menjadi halangan untuk melangsungkan perkawinan atau larangan yang dapat menjadikan tidak sahnya suatu perkawinan yaitu sebagai berikut : 5

a.) Telah ada ikatan perkawinan sebelumnya (1085:1)

b.) Salah seorang calon mempelai bukan Katolik (Kan 1086)

c.) Calon mempelai mempunyai hubungan darah dalam garis lurus ke atas atau ke bawah baik sah maupun tidak sah (Kan 1091 : 1-4)

Salah satu larangan perkawinan menurut agama Katolik yaitu salah satu calon mempelai bukan beragama Katolik.Jadi menurut agama Katolik perbedaan agama dapat mengakibatkan perkawinan menjadi tidak sah.Gereja Katolik berpendapat bahwa perkawinan antara seorang beragama Katolik dengan yang bukan agama Katolik bukanlah bentuk perkawinan yang ideal, karena perkawinan dianggap sebagai sebuah sakramen (sesuatu yang kudus, yang suci). ${ }^{6}$

d. Perkawinan berbeda agama menurut agama Hindu

Agama Hindu memandang perkawinan sebagai sesuatu yang suci. Sahnya perkawinan menurut agama Hindu adalah apabila dilakukan menurut hukum dan

\footnotetext{
${ }^{5}$ Hilman Hadikusuma, Hukum Perkawinan Indonesia Menurut Perundangan, Hukum Adat, Hukum Agama, (Bandung: Mandar Maju, 2003), halaman 67

6 Ahmad Baso dan Ahmad Nurcholish, Pernikahan Beda Agama, Kesaksian, Argumen

Keagamaan dan Analisis Kebijakan, (Jakarta : Komnas HAM, 2005), halaman 207
} 
tata cara agama Hindu yang telah diatur oleh Dharma (agama) dan harus tunduk pada Dharma. Apabila suatu perkawinan tidak dilakukan menurut hukum agama maka akibatnya adalah bahwa segala akibat hukum yang timbul dari perkawinan tersebut tidak diakui sah oleh agama, karena sahnya perkawinan tergantung kepada hukum agama maka syarat-syarat yang harus dipenuhi untuk sahnya suatu perkawinan pun harus memenuhi ketentuan hukum agama (Dharma). Adapun syarat-syarat perkawinan menurut hukum agama Hindu yang terdapat dalam kitab Manava adalah : ${ }^{7}$

a.) Apabila dilakukan di hadapan Brahmana atau pendeta atau pejabat agama yang memenuhi syarat untuk melakukan perbuatan itu

b.) Dilaksanakan berdasarkan hukum Hindu, jadi kedua calon suami isteri harus menganut agama Hindu. Apabila diantara calon pengantin terdapat perbedaan agama maka perkawinan tersebut tidak dapat disahkan kecuali pihak yang bukan Hindu telah di-sudhi-kan (disahkan) sebagai pemeluk agama Hindu

c.) Bagi pria sudah mencapai umur 18 tahun dan wanita mencapai umur 15 tahun

Dari syarat-syarat sahnya perkawinan menurut agama Hindu yang telah diuraikan di atas maka menurut agama Hindu tidak memungkinkan perkawinan dilakukan jika kedua mempelai terdapat perbedaan agama.

e. Perkawinan berbeda agama menurut agama Budha

Perkawinan menurut agama Budha adalah sebagai suatu ikatan suci yang harus dijalani dengan cinta dan kasih sayang seperti yang diajarkan Budha. ${ }^{8}$

Syarat-syarat perkawinan menurut hukum agama Budha adalah sebagai berikut : 9

a.) Kedua mempelai harus saling menyetujui dan saling mencintai

b.) Kedua mempelai harus sudah mencapai umur 21 tahun

c.) Diantara keduanya tidak ada hubungan darah atau hubungan susuan

d.) Kedua mempelai tidak terikat tali perkawinan dengan orang lain

\footnotetext{
${ }^{7}$ Asmin, Status Perkawinan Antar Agama Ditinjau Dari Undang-Undang Perkawinan Nomor 1/1974, (Jakarta: PT Dian Rakyat, 1986), halaman 47

${ }^{8} \mathrm{Ibid}$, halaman 50

${ }^{9}$ Hilman Hadikusuma, Op.Cit, halaman 32
} 
e.) Dan perkawinan dilakukan menurut agama Budha yang berarti harus samasama yakin kepada Sang Tri Ratna.

Dilhat dari syarat-syarat perkawinan menurut hukum agama Budha tersebut tidak ada syarat yang mengharuskan kedua calon mempelai untuk beragama Budha karena sebenarnya dalam agama Budha, perkawinan berbeda agama tidaklah menjadi masalah asalkan perkawinan dilaksanakan mengikuti tata cara agama Budha. Menurut keputusan Sangah Agung Indonesia, perkawinan berbeda agama dimana salah seorang calon mempelai tidak beragama Budha diperbolehkan asal pengesahan perkawinannnya dilakukan menurut tata cara agama Budha. Dalam hal ini calon mempelai yang tidak beragama Budha tidak diharuskan untuk masuk agama Budha terlebih dahulu.Akan tetapi dalam acara ritual perkawinan, kedua mempelai diwajibkan mengucapkan "atas nama Sang Budha, Dharma dan Sangka" yang merupakan dewa-dewa umat Budha. Jadi, meskipun calon yang beragama non Budha tidak diharuskan untuk beragama Budha tetapi dalam pelaksanaan perkawinan calon mempelai yang beragama non Budha harus bersedia untuk mengikuti syarat-syarat sesuai aturan agama Budha seperti mengucapkan janji-janji atas nama Sang Budha, Dharma dan Sangka. Bagi umat Budha, dengan mengucapkan kata-kata tersebut maka secara tidak langsung yang beragama non Budha telah dianggap menganut agama Budha tanpa mengharuskan untuk meyakini agama Budha meskipun sebenarnya hanya menundukkan diri pada kaidah agama Budha dalam pelaksanaan perkawinan tersebut. $^{10}$

2.) Perkawinan berbeda agama menurut Kompilasi Hukum Islam

Dalam Kompilasi Hukum Islam (KHI), penjelasan tentang perkawinan berbeda agama diatur dalam buku I pada Pasal 40 huruf (c) dan Pasal 44 KHI, kedua Pasal tersebut menyatakan:

\section{Pasal 40}

Dilarang melakukan perkawinan antara seorang pria dengan seorang wanita karena keadaan tertentu, huruf (c); seorang yang tidak beragama Islam.

$$
\text { Pasal } 44
$$

\footnotetext{
${ }^{10}$ Ibid, halaman 11
} 
Seorang wanita Islam dilarang melangsungkan perkawinan dengan seorang pria yang tidak beragama Islam

Dari kedua Pasal tersebut dapat diketahui bahwa KHI melarang segala bentuk perkawinan berbeda agama, baik itu perkawinan pria muslim dengan wanita non muslim maupun sebaliknya.

3.) Perkawinan berbeda agama menurut Undang-undang Nomor 1 Tahun 1974

Menurut Undang-undang nomor 1 tahun 1974, mengenai perkawinan berbeda agama di Indonesia tidaklah dikehendaki oleh Undang-undang ini. Hal tersebut dengan tegas dinyatakan dalam Pasal 2 ayat (1) mengenai sahnya perkawinan yang berbunyi: Perkawinan adalah sah, apabila dilakukan menurut hukum masing-masing agamamya dan kepercayaannya. Selain itu, juga dinyatakan dalam Pasal 8 huruf (f) yang berbunyi: perkawinan dilarang antara dua orang yang mempunyai hubungan yang oleh agamanya atau peraturan lain yang berlaku, dilarang kawin. Artinya adalah dengan merujuk kedua Pasal tersebut maka dengan ini Undang-undang perkawinan melarang dilangsungkan atau disahkan perkawinan yang dilarang oleh agama dan peraturan lain yang berlaku di negara Indonesia. Larangan yang termuat dalam Undang-undang perkawinan ini selaras dengan larangan agama dan hukum masing-masing agama yang telah di jelaskan diatas.Oleh karena itu, pembenaran dan pengesahan perkawinan berbeda agama selain bertentangan dengan agama sebenarnya juga bertentangan dengan Undang-undang perkawinan yang berlaku bagi setiap warga negara dan penduduk Indonesia. ${ }^{11}$

\section{Akibat Hukum dari Perkawinan Berbeda Agama di Indonesia}

1.) Akibat hukum terhadap status perkawinan

Merujuk pada Pasal 2 ayat (1) jo Pasal 8 huruf f Undang-Undang Nomor 1 Tahun 1974 maka menurut penulis Undang-Undang perkawinan cenderung menyerahkan sepenuhnya kepada hukum agama masing-masing untuk menentukan boleh tidaknya perkawinan berbeda agama.

\footnotetext{
${ }^{11}$ Mohammad Daud Ali, Hukum Islam Dan Peradilan Agama, (Jakarta: Raja Grafindo Persada, 2002), halaman 70
} 
Semua agama di Indonesia melarang perkawinan berbeda agama, bagi umat Islam setelah dikeluarkannya Instruksi Presiden Nomor 1 Tahun 1991 tentang Kompilasi Hukum Islam, pada Pasal 44 menyatakan bahwa perkawinan campuran berbeda agama, baik itu laki-laki muslim dengan wanita non muslim, telah dilarang secara penuh. Begitu pula dengan agama Kristen yang melarang perkawinan berbeda agama antara umat Kristen dengan non Kristen, sama halnya dengan agama-agama lain yang melarang umatnya melakukan perkawinan dengan pasangan yang berbeda agama. Oleh karena semua agama melarang perkawinan berbeda agama maka perkawinan berbeda agama juga dilarang oleh UndangUndang Nomor 1 Tahun 1974 dan hal tersebut mengakibatkan perkawinan tersebut tidak sah.

2.) Akibat hukum terhadap status dan kedudukan anak

Anak sah berdasarkan Pasal 42 Undang-Undang Nomor 1 Tahun 1974 yaitu anak yang dilahirkan dalam atau sebagai akibat perkawinan yang sah. Demikian juga dengan ketentuan Pasal 99 Kompilasi Hukum Islam yang menyatakan bahwa anak yang sah adalah anak yang dilahirkan dalam atau akibat perkawinan yang sah.Dari ketentuan-ketentuan tersebut dapat dikatakan bahwa untuk menentukan sah atau tidaknya anak tergantung pada sah atau tidaknya suatu perkawinan. Maka menurut pendapat penulis, anak dari hasil perkawinan berbeda agama adalah anak tidak sah atau anak luar kawin karena perkawinan kedua orangtuanya pun tidak sah menurut hukum agama atau hukum perkawinan. Oleh karena itu, anak yang dilahirkan dari perkawinan berbeda agama adalah anak tidak sah atau anak luar kawin, maka akibatnya adalah anak tersebut tidak memiliki hubungan perdata dengan ayahnya, si anak hanya memiliki hubungan perdata dengan ibu dan keluarga ibunya saja. Hal tersebut diatur dalam Pasal 43 ayat (1) Undang-Undang Nomor 1 Tahun 1974 dan Pasal 100 Kompilasi Hukum Islam yang menyebutkan bahwa anak yang lahir di luar perkawinan hanya mempunyai hubungan nasab dengan ibunya dan keluarga ibunya.

3.) Akibat hukum dalam status administrasi kependudukan

Jika merujuk pada Pasal 37 ayat (1) Undang-undang Nomor 23 Tahun 2006 tentang Administrasi Kependudukan, perkawinan berbeda agama yang 
dilakukan di luar negara Indonesia pencatatan perkawinannya dilakukan di negara dimana perkawinan itu dilangsungkan baru kemudian perkawinan tersebut dilaporkan di Indonesia. Adapun tata cara pelaporan perkawinan yang dilangsungkan di luar negara Indonesia telah di atur dalam Pasal 70 Peraturan Presiden Republik Indonesia Nomor 25 Tahun 2008 tentang Persyaratan dan Tata Cara Pendaftaran Penduduk dan Pencatatan Sipil.

Jadi, perkawinan berbeda agama Warga Negara Indonesia jika telah dicatatkan / dilaporkan di pencatatan sipil Indonesia adalah perkawinannya telah diakui oleh hukum negara dimana perkawinan tersebut dilangsungkan. Namun kembali lagi kepada Undang-Undang Nomor 1 Tahun 1974 yang urusan mengenai perkawinan lebih diserahkan kepada hukum masing-masing agama yang mengaturnya, meskipun dengan melakukan berbagai macam cara untuk melegalkan perkawinan yang berbeda agama hingga menempuh jalan ke luar negeri, tetap saja menurut hukum-hukum agama yang ada di Indonesia bahwa perkawinan yang dilakukan oleh pasangan yang berbeda agamanya adalah di larang dan itu artinya perkawinan mereka tidak sah menurut hukum agama karena cara yang ditempuh dengan melangsungkan perkawinan di luar negara Indonesia adalah mengesampingkan urusan agama.

Kemudian mengenai anak yang di lahirkan dari perkawinan berbeda agama, karena menurut hukum agama perkawinan berbeda agama adalah tidak sah maka anak yang dilahirkan pun juga merupakan anak tidak sah.Namun meskipun demikian, setiap anak yang lahir tetap harus dicatatkan pada catatan sipil untuk dapat memperoleh akta kelahiran.Adapun hal tersebut di atur dalam Pasal 27 Undang-undang Nomor 23 Tahun 2006 tentang Administrasi Kependudukan. Sedangkan tata cara pencatatan kelahiran diatur dalam Pasal 51 Pasal 54 Peraturan Presiden Republik Indonesia Nomor 25 Tahun 2008 tentang Persyaratan dan Tata Cara Pendaftaran Penduduk dan Pencatatan Sipil.

\section{Penutup}

\section{Simpulan}

Berdasarkan pembahasan tersebut maka dapat disimpulkan bahwa : 
1.) Perkawinan berbeda agama menurut Undang-undang Nomor 1 Tahun 1974 adalah perkawinan yang tidak sah. Oleh karena itu, pembenaran dan pengesahan perkawinan berbeda agama selain bertentangan dengan agama, sebenarnya juga bertentangan dengan Undang-undang Nomor 1 Tahun 1974.

2.) Akibat hukum dari perkawinan berbeda agama di Indonesia adalah status perkawinan berbeda agama tersebut tidak sah menurut masing-masing agama sehingga tidak sah juga menurut UU Perkawinan. Dengan adanya status perkawinan yang tidak sah tersebut maka membawa akibat juga terhadap status dan kedudukan anak. Anak-anak yang dilahirkan dalam perkawinan berbeda agama adalah anak tidak sah karena perkawinan kedua orangtuanya bukan merupakan perkawinan yang sah. Sehingga akibatnya adalah anak tersebut tidak mempunyai hubungan hukum dengan ayahnya melainkan hanya dengan ibu dan keluarga ibunya saja. Hal tersebut sesuai dengan Pasal 43 ayat (1) UU Perkawinan dan Pasal 100 KHI. Namun meskipun demikian, setiap anak yang lahir tetap harus dicatatkan pada catatan sipil untuk dapat memperoleh akta kelahiran. Ketentuan tersebut di atur dalam Pasal 27 UU Nomor 23 Tahun 2006 dan tata caranya diatur dalam Pasal 51-53 Perpres Nomor 25 Tahun 2008.

\section{Saran}

1.) Saran untuk pemerintah

Peraturan masalah perkawinan berbeda agama dirasa kurang tegas karena dalam Undang-undang Nomor 1 Tahun 1974 tidak secara tegas dan jelas menyebutkan bahwa perkawinan berbeda agama di larang. Undang-undang perkawinan hanya mengatur mengenai sahnya perkawinan dimana sahnya suatu perkawinan harus dilakukan menurut hukum masing-masing agana dan kepercayaan. Dan juga pada Pasal 8 huruf (f) mengenai larangan perkawinan tidak disebutkan mengenai larangan perkawinan berbeda agama. Pasal 8 huruf (f) hanya menyatakan bahwa perkawinan dilarang antara dua orang yang mempunyai hubungan yang oleh agamanya atau peraturan lain yang berlaku dilarang. Dalam Undang-undang Nomor 1 Tahun 1974 tidak ada satu Pasal pun yang menyebutkan secara tegas bahwa perkawinan berbeda agama dilarang. Oleh karena itu saran 
penulis kepada pemerintah adalah sebaiknya masalah perkawinan berbeda agama diatur secara tegas dan jelas didalam Undang-undang Nomor 1 Tahun 1974 dengan cara melakukan perubahan Undang-undang ini dan memasukkan masalah perkawinan berbeda agama dalam satu Pasal.

2.) Saran untuk masyarakat

Saran penulis untuk masyarakat adalah sebaiknya masyarakat Indonesia lebih patuh akan adanya Undang-undang yang berlaku di Indonesia dan juga lebih mematuhi apapun peraturan sesuai hukum agamanya masing-masing. 


\section{Daftar Pustaka}

\section{Buku}

Ali, Mohammad Daud. 2002. Hukum Islam dan Peradilan Agama.Jakarta: Raja Grafindo Persada

Asmin. 1986. Status Perkawinan antar Agama ditinjau dari Undang-undang Perkawinan No. 1 Tahun 1974. Jakarta: Dian Rakyat

Baso, Ahmad dan Ahmad Nurcholish. 2005. Pernikahan Beda Agama,Kesaksian, Argumen Keagamaan dan Analisis Kebijakan. Jakarta:Komnas HAM

Hadikusuma, Hilman. 2003. Hukum Perkawinan Indonesia menurutPerundangan, Hukum Adat, Hukum Agama. Bandung: Mandar Maju

Soimin, Soedharyo. 2004. Hukum Orang dan Keluarga Perspektif HukumPerdata Barat/BW, Hukum Islam, dan Hukum Adat. Jakarta: SinarGrafika

Syarifuddin, Amir. 2007. Hukum Perkawinan Islam di Indonesia AntaraFiqh Munakahat dan Undang-Undang Perkawinan. Jakarta: PrenadaMedia

\section{Peraturan Perundang-undangan}

Undang-Undang Nomor 1 Tahun 1974 tentang Perkawinan

Undang-Undang Nomor 23 Tahun 2006 tentang Administrasi Kependudukan

Peraturan Presiden Republik Indonesia Nomor 25 Tahun 2008 tentangPersyaratan dan Tata Cara Pendaftaran Penduduk dan Pencatatan Sipil Kompilasi Hukum Islam 